\title{
The Effect of Organizational Justice and Islamic Working Ethic on the Organizational Commitment of Lecturers
}

\author{
$1^{\text {st }}$ Yunus Mustaqim \\ Departement of Islamic Economic, \\ Universitas Muhammadiyah Kudus \\ Kudus Jawa Tengah, Indonesia \\ yunusmustaqim@umkudus.ac.id
}

\author{
$2^{\text {nd }}$ Mariyatin \\ Departement of Islamic Economic, \\ Universitas Muhammadiyah Kudus \\ Kudus Jawa Tengah, Indonesia \\ mariyatin@gmail.com
}

\author{
$3^{\text {rd }}$ Jati Prihantono \\ Departement of Islamic Economic, \\ Universitas Muhammadiyah Kudus \\ Kudus Jawa Tengah, Indonesia \\ jatiprihantono@gmail.com
}

\begin{abstract}
Organizational justice provides satisfaction of individual employees. Therefore, the Islamic working ethic explains the existence of working ethic that has a good faith, both are interrelated each other to measure the extent of the organizational commitment in requiring lecturers and understanding of organizational justice in the Islamic working ethic. Thus, this study aims to examine empirically the effect of organizational justice and Islamic working ethics on the organizational commitment of the lecturers of Muhammadiyah University of Kudus. This study applied descriptive quantitative approach by using a questionnaire method that directly distributed to 86 lecturers. In addition, the data was also obtained by proportionate stratified random sampling and multiple linear regressions. The results of this study are: 1) Organizational justice has a positive and significant influence on organizational commitment of the lecturers of Muhammadiyah University of Kudus as it is known by the value of $t_{\text {count }}>t_{\text {table, that }}$ is $\left.t_{\text {count }} 4.587>t_{\text {table }} 1.662 ; 2\right)$ Islamic working ethic has a positive and significant influence on organizational commitment of the lecturers of Muhammadiyah University of Kudus as it is known by the value of $t_{\text {count }}>t_{\text {table, that is, }}$ $t_{\text {count }} 4.197>t_{\text {table }}$ 1.662; and 3 ) Organizational justice and Islamic working ethic have a positive and significant influence on the organizational commitment of the lecturers of Muhammadiyah University of Kudus as it is known by the value of $F_{\text {count }}>F_{\text {table, }}$ which is $F_{\text {count }} 26.155>F_{\text {table }}$ 3.10.
\end{abstract}

Keywords-Organizational, Islamic, Ethics, Commitment

\section{INTRODUCTION}

Organizational justice has an impact on the reaction of someone or private or public employees who work in organizations or companies. Fairness needed for every employee to get a reward through distribution, procedures and interactional justice. The intended benefit is the opportunity to express a personal opinion on the decision to be made by the company as an organization; work procedures that are consistent from time to time; decision makers pay attention to the needs of each individual; the information provided by the company as an organization is accurate so it is not confusing; open opportunities to correct any work mistakes that have been made and as well as established work procedures that pay attention to ethical principles [1].
Relation to the Islamic work ethic that employees have work habits based on the system of faith or Islamic aqeedah as the basic attitude of life [2]. That is, that the Islamic work ethic will give an image to employees to always work in accordance with Islamic values. This is in accordance with the vision of the Muhammadiyah University of Kudus which provides work rules in accordance with Islamic values, such as when the prayer time arrives so that all employees are required to carry out the congregation in addition to that employees must also always maintain aqidah when working in order to have a good commitment to the organization.

Commitment to the organization is one important aspect of behavior that can be used to evaluate the strength of a leader and employee of the organization at work. According to [3], commitment in organizing as a psychological construct is a characteristic of the relationship between organizational members and their organizations and has implications for the individual's decision to continue his membership in the organization. This means that members (employees) who have an organizational commitment to their organization will be abler to survive as part of the organization than members (employees) who do not have commitment to the organization.

As a study conducted [4], organizational justice is a significant determinant in organizational commitment. Relation to the Islamic work ethic of organizational commitment, this is in accordance with research conducted [5], that the Islamic work ethic has a positive and significant effect on organizational commitment. Other research was also conducted [6], the study proposed to investigate the effect of Islamic work ethic on justice perception among employees in Islamic microfinance institutions in Indonesia. The construct of organizational justice included three dimensions, namely, distributive, procedural, and interactional justice. The results suggested that Islamic work ethic positively contributed to the three dimensions of justice perception.

Seeing from a variety of research conducted by previous researchers that there are problems that often occur and become a highlight one of them is the factor of organizational justice. Then there is a gap research that 
organizational commitment to employees is not optimal. So that this research is new to previous research, meaning that the researcher focuses on the dependent variable, namely organizational commitment that is different from previous studies. Research by researchers wants to find out how far the influence of organizational justice and Islamic work ethic on organizational commitment to the lecturers of Muhammadiyah University of Kudus.

\section{LITERATURE REVIEW}

\section{A. Organizational Justice}

Employees who work in a company or organization will expect the company to be able to treat it fairly. According to [3] that there are two perspectives on fairness used are a) According to equity theory, employees consider participation in the workplace as a barter process, which is to make contributions such as expertise and hard work, and instead expect work results, either in the form of salary or recognition. Here, the emphasis is on perceptions of fairness between what employees get relative to what they contribute. b) Another way to see organizational justice is through the concept of procedural justice. The emphasis is on whether the procedures used to share work results with employees are fair enough or not.

\section{B. Islamic Work Ethic}

The Islamic work ethic provides a view of high dedication in working hard as a mandatory obligation. Sufficient effort must be part of one's work, which is seen as a liable individual obligation. According to [7], the Islamic work ethic emphasizes cooperation in work, and the concept of consultation is seen as a way to overcome obstacles or problems and avoid mistakes. Social relationships at work are drivers that aim to bring together a person's needs and strike a balance between individual needs and social life. The Islamic work ethic also puts pressure on work which on average can help personal growth or progress, respect for oneself or others, job satisfaction, and self-empowerment. Besides the pressure to work creatively can be a source of pleasure and achievement. Working hard is seen as kindness, and anyone who works hard will be more likely to get progress in his life and vice versa, if you do not want to work hard it will be seen as a cause of failure in life. A description of the formation of a work ethic, as explained [2], both those without religious involvement or those that are Islamic can be simply described below:

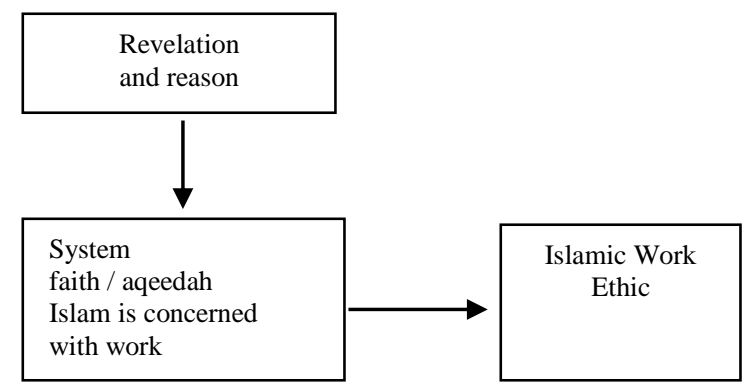

Figure 1. The Paradigm for the Establishment of an Islamic Work Ethic
The Islamic work ethic emanates from the Islamic system of faith / aqeedah regarding work. Aqidah is formed from the teachings of revelation and reason that work together proportionally according to their respective functions.

Understanding business ethics from Islamic perspective has become important for business currently [8]. Islamic work ethics is a set of values or system of beliefs that are derived from the Quran and Hadith concerning work and hard work [9]. Islamic work ethics is important to be examined in relation to job satisfaction and organizational justice, at least for two reasons. First, Islamic work ethics is multi-dimensional and related to various aspects of life such as social, political, and economics [10]. Second, the role of Islamic work ethics in organizational justice has not received adequate attention in the literature [6], especially in the context of an accountant profession.

\section{Organizational Commitment}

Commitment has the meaning of strong acceptance within the individual towards the goals and values of the company, so that the individual will try and work and has a strong desire to stay afloat in the company. So that commitment to the organization reflects three main dimensions, namely, commitment is seen to reflect an affective orientation to the organization, consideration of the disadvantages of leaving the organization, and moral burdens to remain in the organization. aMeyer and Allen as quoted [3] and [1] formulate three dimensions of commitment in an organization, namely: affective, continuance, and normative. These three things are more accurately stated as components or dimensions of organizational commitment, rather than types of organizational commitment.

\section{RESEARCH METHODS}

The type of research used is field research with a quantitative approach. The population in this study were all lecturers of Muhammadiyah University of Kudus, totaling 113 people. This study uses a proportionate stratified random sampling technique, which is collecting data from a population carried out randomly without regard to strata that exist in that population [11]. By using an error level of 5\%, a sample of 86 lecturers was obtained. Variables used in research can be classified into two, namely:

1. Independent variables, namely variables that explain and influence other variables. The independent variables in this study are organizational justice and Islamic work ethic.

2. The dependent variable (dependent variable) is the variable explained and influenced by the independent variable. The dependent variable in this study is organizational commitment.

The steps in the multiple regression analysis are as follows: (1) knowing the coefficient of determination test (2) analyzing the simulant test (F test) (3) analyzing the partial test ( $\mathrm{t}$ test) and (4) making a regression equation. 


\section{RESULT AND DISCUSSION}

Partial testing (t-test) aims to test or confirm individually. This partial test contained in the results of statistical calculations is indicated by $t_{\text {count }}$. The results of calculations carried out using SPSS version 26 are as follows:

TABLE I. PARTIAL TEST Results

\begin{tabular}{|l|l|l|l|}
\hline \multicolumn{2}{|c|}{ Model } & \multicolumn{1}{c|}{$t$} & Sig. \\
\hline \multicolumn{2}{|c|}{ Coefficients } \\
\hline \multirow{2}{*}{1} & (Constant) & & \\
\cline { 2 - 4 } & Organizational Justice & 6.087 & .000 \\
\cline { 2 - 4 } & Islamic Work Ethic & 4.587 & .000 \\
\hline \multicolumn{3}{|c|}{ a. Dependent Variable: Organizational Commitment } \\
\hline
\end{tabular}

a. Effect of Organizational Justice on Organizational Commitment

From the results of data processing above, it can be seen that the $t_{\text {count }}>t_{\text {table }}$. It can be seen that the $t_{\text {count }}$ is $4.587>\mathrm{t}_{\text {table }}$ for 1.662 with a significance level below $5 \%$ which means that there is an influence between organizational justice and organizational commitment at the lecturers of Muhammadiyah University of Kudus. Because someone's assessment of justice is not only influenced by what they receive as a result of certain decisions, but also on the process or how the decision is made. Then if employees or employees judge that the treatment they receive is fair it will affect two types of outcomes they receive, namely satisfaction and commitment. The higher they perceive the fairness of a policy or management practice will have an impact on increasing job satisfaction and organizational commitment within the lecturer. And so far the organizational justice in the Muhammadiyah University of Kudus is felt by lecturers, meaning that lecturers receive distributive justice in accordance with their level, lecturers are invited to deliberations for the benefit of the institution as well as lecturers are given the opportunity to improve their careers according to procedures. This is in accordance with research conducted [4] that procedural justice and distributive justice, as dimensions of organizational justice, are significant determinants of organizational commitment. The same thing was done [5] in their research resulting that organizational justice has a significant influence on organizational commitment.

Another study was also conducted by [12] on male and female school managers in Iran. This study showed that there was a positive relationship between Islamic work ethics with procedural justice and interactive justice, but not with distributive justice. Another study was conducted by [8] on medical faculty members of a large private university in Pakistan. Their study showed that Islamic work ethics could reduce employees' turnover intentions when the organization implemented procedural justice and distributive justice. While [13] carried out a study on officers in the Police Department of Iran. Their study found that Islamic work ethics could encourage the implementation of organizational justice. b. Effect of Islamic Work Ethic on Organizational Commitment

The results of statistical data processing using computerization is known that there is an influence between the Islamic work ethic on organizational commitment to the lecturers of Muhammadiyah University of Kudus. It can be seen that the $t_{\text {count }}$ is 4.197 $>t_{\text {table }}$ of 1.662 with a significance level below $5 \%$. Because the role of human resources in advancing the company is very important. One approach to improving the quality of human resources is through a religious approach. In Islam there is an Islamic work ethic concept based on the Qur'an and examples of the Prophet Muhammad SAW, such as working in accordance with Islamic teachings, namely when it is time to pray all the lecturers of Muhammadiyah University of Kudus perform congregational prayers, greet each other when they meet, work with teams and etcetera. This is according to research conducted[14] that the Islamic work ethic has a positive and significant effect on commitment. The same thing was done[5]in their research that Islamic work ethic has a significant influence on organizational commitment. c. Simultaneous Test (F Test)

Simultaneous test is intended with the results of the $F_{\text {count }}$ calculation. The results of data processing using SPSS version 26 are known as follows:

TABLE II. Simultaneous Test Results

\begin{tabular}{|c|c|c|c|c|}
\hline \multicolumn{5}{|c|}{ ANOVA $^{a}$} \\
\hline \multicolumn{2}{|c|}{ Model } & Mean Square & $\boldsymbol{F}$ & Sig. \\
\hline \multirow[t]{3}{*}{1} & Regression & 116.924 & 26.155 & $.000^{\mathrm{b}}$ \\
\hline & Residual & 4.470 & & \\
\hline & Total & & & \\
\hline \multicolumn{5}{|c|}{ a. Dependent Variable: Commitment } \\
\hline & & tors: (Const & $\operatorname{mic~E}$ & ional \\
\hline
\end{tabular}

Based on the table above, it can be seen that the value of $F_{\text {count }}$ is 26.155. This means that the value has a large influence jointly between organizational justice and the Islamic work ethic of organizational commitment. This can be seen from the value of $F_{\text {count }}>F_{\text {table }}(26.155>3.10)$ with a probability level of 0.000 .

\section{CONCLUSION}

Based on the discussion above, it can be concluded that organizational justice has an influence on organizational commitment at the lecturers of Muhammadiyah University of Kudus. It is proven from the results of data processing that it can be seen that the $t_{\text {count }}>t_{\text {table }}$, that is, the $t_{\text {count }}$ of $4.587>t_{\text {table }}$ of 1.662 with a significance level below $5 \%$ means that there is fair treatment for lecturers in the organization, there are similarities in the welfare of lecturers in the organization, lecturer involvement in organizational decisions, lecturer involvement in organizational development, consistency in procedures, superior treatment of lecturers and openness of superiors to subordinates.

Islamic work ethic also has an influence on organizational commitment at the lecturers of Muhammadiyah University of Kudus. It is proven from the results of data processing that it can be seen that the 
value of $t_{\text {count }}>t_{\text {table }}$, that is $t_{\text {count }}$ of $4.197>t_{\text {table }}$ of 1.662 with a significance level of below $5 \%$ means the role of lecturers in advancing the institution or organization is very important. One approach in improving the quality of human resources (lecturers) is through a religious approach, as practiced at the Muhammadiyah University of Kudus. Paying close attention to the existence of an Islamic work ethic by manifesting through various religious activities, such as a cult when conducting coordination meetings, reading the Qur'an, congregational prayers and so forth so that this will provide a sense of comfort and pleasure in working for lecturers to commit to the institution or organization.

The theoretical implication of this research is that to increase the level of organizational commitment the institution or organization must pay attention to organizational justice and the Islamic work ethic. Likewise, it also needs to be a concern of management in maintaining human resources, namely by paying more attention to matters related to organizational commitment, of course by not ignoring other things that have been going well in terms of improving human resources. To obtain better and more accurate study results, it is necessary to test the factors that influence organizational commitment by adding more.

this is in accordance with research conducted by [15], et al The study also found that Islamic work ethics affects organizational commitment and its three dimensions; affective, normative and continuance commitment

\section{ACKNOWLEDGMENT}

I would like to express my special thanks of gratitude to my rector (Rusnoto, SKM., M.Kes (Epid)) as well as chairperson of LPPM (Noor Cholifah, S.Sit., M.Kes)who gave me the golden opportunity to do this wonderful project on the topic (the effect of organizational justice and Islamic working ethic on the organizational commitment of lecturers in Muhammadiyah University of Kudus), which also helped me in doing a lot of Research and I came to know about so many new things I am really thankful to them.

Secondly I would also like to thank my parents and lecturers who helped me a lot in finalizing this project within the limited time frame.

\section{REFERENCES}

[1] Y. Budiarto, and R. P. Wardani, "Komitmen Karyawan Pada Perusahaan ( Studi Pada Perusahaan X )," J. Psikol., vol. 3, no. 2, pp. 109-126, 2005.

[2] A. Asifudin, "Etos Kerja Islami," Yogyakarta: UII Pers, 2004.

[3] K. Umam, "Perilaku Organisasi," Bandung: Pustaka Setia, 2012.

[4] S. Hwei, and T. E. C. Santosa, "Pengaruh Keadilan Prosedural Dan Keadilan Distributif Terhadap Komitmen Organisasi,” J. Din. Ekon. Bisnis, vol. 9, no. 2, pp. 37-52, 2012.

[5] D. S. W. Y. Mustaqim, "Pengaruh kepemimpinan kenabian dan etos kerja islami terhadap komitmen organisasi," Equilib. J. Ekon. Syariah, vol. 4, no. 2, pp. 269-283, 2016.

[6] A. Hassan, and W. Rokhman, "The effect of Islamic work ethic on organisational justice," African J. Bus. Ethics, vol. 6, no. 1, 2014.

[7] T. Tasmara, "Membudayakan Etos Kerja Islami," Jakarta: Gema Insani Pres, 2002.

[8] U. Khan, K. Abbas, M. Gul, and A. Raja, "Organizational justice and job outcomes: moderating role of Islamic work ethic," J. Bus. Ethics, vol. 126, pp. 235-246, 2015.

[9] W. Rokhman, "The effect of Islamic work ethics on work outcomes,” J. Bus. Ethics Organ. Stud., vol. 1, pp. 7-21, 2010.

[10] M. Y. Ahmad, and S. Owoyemi, "The concept of Islamic work ethic: An analysis of some salient points in the Prophetic Tradition,” Int. J. Bus. Soc. Sci., vol. 20, pp. 217-225, 2012.

[11] Sugiyono, "Metodelogi Penelitian Kuantitatif, Kualitatif Dan R \& D," Bandung: Alfabeta, 2013

[12] R. Farahizade, and Z. Belaghat, "Study of the relationship between Islamic ethics-based management and organizational justice and commitment among managers of different schools at Zahedan preprovince,” Int. Res. J. Appl. Basic Sci., vol. 7, pp. 1783-1790, 2013.

[13] Y. Z. Farsi, J. Y. Shiraz, R. P. Rodgarnezhad, and F. Anbardan, "Investigating the relationship between Islamic work ethics and organizational justice and its components: a case study of gilan province police employees," J. UMP Soc. Sci. Technol. Manag., vol. 2, pp. 238-244, 2015.

[14] I. W. M. Indica, "Pengaruh Etos Kerja Islami dan Gaya Kepemimpinan Transformasional terhadap Komitmen Organisasional dan Kinerja Karyawan (Studi Pada Waroeng Stike And Shake di Kota Malang)," Malang: Brawijaya, 2012.

[15] S. N. bin Salahudina, S. S. Binti Baharuddina, M. S. Abdullah, and A. Osmanc, "No TitleThe Effect of Islamic Work Ethics on Organizational Commitment," Procedia Econ. Financ., vol. 35, pp. 582-590, 2016. 